\title{
The Age-Indifference Principle and Equality
}

\author{
JOHN HARRIS
}

The question of whether or not either elderly people or those whose life expectancy is short have commensurately reduced claims on their fellows, have, in short, fewer or less powerful rights than others, is of vital importance but is one that has seldom been adequately examined. Despite ringing proclamations of justice and equality for all, the fact is that most societies discriminate between citizens on the basis both of age and life expectancy.

Simona Giordano's important paper ${ }^{1}$ explores the gulf between theory and practice. It examines the support given to theoretical equality by international instruments and conventions, and constitutes a ringing endorsement of a theory of equality that has its origins in Plato and Aristotle but to which contemporary societies are no less bound or committed.

In this paper I seek to provide an account complementary to that developed by Dr. Giordano of the moral reasons for age indifference both in ethics and in public policy and incidentally attribute the force of this account to an English philosopher, Thomas Hobbes, rather than to his, perhaps more famous, Greek forebears.

\section{Age-Relative Moral Claims}

There are three obvious ways in which it might be thought that moral claims could be age relative. One is that they might be thought to vary with elapsed time, that they might diminish (or perhaps even increase) in proportion to the amount of lifetime an individual had experienced or "consumed." 2 The second way in which moral claims might be thought to be age relative concerns not lifetime lived, but lifetime in prospect. It is often thought that moral claims vary with life expectancy, in proportion to the amount of lifetime an individual had left or (more likely) is reasonably expected to have left. This will always, of course, be related to elapsed lifetime, but may also arise through illness, injury, genetic constitution, or, indeed, may be related to social class, domicile, or access to healthcare or life-prolonging strategies or technologies as and when they become available. Finally, many think that moral claims are legitimately varied by quality of life considerations, for example, that people with very poor quality of life are not worth (or are less worth) the expenditure of healthcare resources. ${ }^{3}$

Quality, quantity, and life expectancy considerations are all combined, of course, in the notorious Quality Adjusted Life Year (QALY) and related methods of prioritizing resources for healthcare. ${ }^{4}$ Elapsed time, on the other hand, features in 


\section{John Harris}

accounts that use some concept of a "fair innings" or "reasonable life span" approach. ${ }^{5}$ All of these accounts reflect significant concerns about the justice of ignoring quantity and quality of life considerations when considering entitlements.

Another increasingly popular suggestion is that an individual's lifestyle choices may affect his or her moral claims or entitlements. This can happen in two main ways, which I shall call, health-related and wealth-related choices.

\section{Health-Related Choices}

Throughout a person's life, she will make many choices and do many things that impact on her health state and life expectancy. These will include choices about diet, drug and alcohol use and abuse, exercise and fitness, choice of domicile (cities are dangerous places-pollution or violent crime abounds; geography is important too-the south of Italy is well known to be more conducive to longevity than the north of England), choice of occupation (occupational risk and health), and indeed sexual habits and practices (numbers of partners, methods of contraception or lack of them, etc.). The list could continue almost indefinitely but there is an increasingly vocal school of thought that suggests that people be held responsible for adverse health that is wholly or partially attributable to their own voluntary choices. ${ }^{6}$

\section{Wealth-Related Choices}

Similarly, an individual will make what I call "wealth-related" choices, choices that determine what disposable resources are available to palliate infirmity and support healthcare and retirement or old age. Such choices will include decisions to spend, save, or invest at various points in life and decisions to insure against various risks or certainties. They will also include decisions like the decision to have children, which may be calculated to reduce resources available for self-support or, under another model of the function of children, to provide support in old age.

We will start by calling it, for want of a more appropriate title, "the anti-ageist argument," but very soon we will need to place this argument in a broader context.

\section{The Anti-Ageist Argument}

One way of formulating the ideas that lie behind opposition to so-called ageism has been stated thus:

All of us who wish to go on living have something that each of us values equally although for each it is different in character, for some a much richer prize than for others, and we none of us know its true extent. This thing is of course "the rest of our lives". So long as we do not know the date of our deaths then for each of us the "rest of our lives" is of indefinite duration. Whether we are 17 or 70, in perfect health or suffering from a terminal disease we each have the rest of our lives to lead. So long as we each ... wish to live out the rest of our lives, however long that turns out to be, then if we do not deserve to die, we each suffer the same injustice if our wishes are deliberately frustrated and we are cut off prematurely. ${ }^{8}$ 
An important element of an anti-ageist position expressed in this way is that it links discrimination on the basis of elapsed lifetime to discrimination on the basis of life expectancy. These are not, of course, necessarily linked. Some people have defended what might be termed a "fair innings argument." 9 This suggests that people are entitled to every opportunity to live a fair life span-perhaps the traditional three score years and ten. Up to that point they have equal entitlement to healthcare; beyond the fair innings they are given very low priority. This argument is tempting because it explains the strong intuition people have that there is something wrong with treating the claims of an octogenarian and those of a 20-year-old as equal. However, the fair innings argument assumes that the value of a life is to be measured in units of lifetime, the more the better up to a certain point, but thereafter extreme discounting begins. The problem is that people value particular events within their lives disproportionately to the time required to experience those events. Although the fair innings argument gives great importance to a life having shape and structure, these things are again not necessarily only achieved within a particular time span. Without having available the vast detail of each person's life and their hopes and aspiration's within that detail, we cannot hope to do justice between lives. Arguably, the only sensible alternative is to count each life for one and none for more than one, whatever the differences in age and in other quality considerations. It is this outlook that explains why murder is always wrong and wrong to the same degree. When you rob someone of life you take from them not only all they have but all they will ever have. The wrongness consists in taking from them something that they want. That is why murder is our paradigm of a wrongful act.

Those who believe in discriminating in favor of the young or against the old must believe that insofar as murder is an injustice, it is less of an injustice to murder the old than the young (though of course not necessarily less of a crime). Because they also believe that life years are a commodity like any other, it is clear that in robbing people of life you take less from them the less life expectancy they have. This is, of course, directly contrary to the way in which the common law tradition has viewed the wrong of ending life prematurely. As the English judge Mars-Jones $\mathrm{J}$ has said in his judgment in a much cited case:

However gravely ill a man may be ... he is entitled in our law to every hour ... that God has granted him. That hour or hours may be the most precious and most important hours of a man's life. There may be business to transact, gifts to be given, forgiveness to be made, 101 bits of unfinished business which have to be concluded. ${ }^{10}$

\section{The Age-Indifference Principle}

An individual's entitlement to the concern, respect and protection of the community does not vary with age or life expectancy. ${ }^{11}$

Clearly this principle is itself the application of a more general principle. That more general principle, which is clearly a principle of equality, may be taken as asserting that each person is entitled to the same concern, respect, and protection of 


\section{John Harris}

society as is accorded to any other person in the community. The principle of equality has the advantage of very wide appeal and acceptance, and versions of it are enshrined in many national constitutions throughout the world ${ }^{12}$ and in various declarations of human rights. ${ }^{13}$ The age-indifference principle reminds us that the principle of equality applies as much in the face of discrimination on the basis of chronological age or life expectancy as it does to discrimination on the basis of gender, race, and other arbitrary features. ${ }^{14}$

\section{The Age-Indifference Principle and Morality}

There is a strong presumption in most societies that a person's moral claims derive from his or her dignity and standing as a human person and are not dependent on any more arbitrary or particular features. It is this generality that is found in almost all declarations of, or conventions on, human rights, as Dr. Giordano's paper shows. If we extend our thoughts to political rights and liberties, then we find a fairly massive consensus that these apply progressively through late childhood and early adolescence and reach their full flower only with the age of majority. At the other end of life it is not uncommon to find progressive disabilities, from a compulsory age of retirement from employment to restrictions on travel and on access to medical treatment.

However, the principle that an individual's entitlement to the concern, respect, and protection of the community does not vary with age or life expectancy accords well with our general view that it is human persons who matter morally, more particularly that their claims on one another derive from their status as beings of a particular sort and not from contingent features of their lives like age, life expectancy, or quality of life no more than from gender or race.

The equality principle applies as much in the face of discrimination on the basis of chronological age or life expectancy as it does to discrimination on the basis of gender, race, and other arbitrary features.

In many ways this is an appeal to common sense morality. Grant that people matter morally, then discrimination between them can be justified only in three main ways: first, only if it can be shown that they are not after all "people" in the relevant sense; second, if the proposed discrimination can be shown to be consistent with the equality principle, if it can be shown to be consistent with treating each with the same concern and respect and to the same protection of the community as is accorded to any; finally, discrimination may be justified on the grounds that it is what the individuals themselves desire or at least have consented to, or, if they are incapable of giving consent, that it is in their best interests.

As I have suggested, this is basic common sense. If you hear that 100 innocent people have been murdered, the offense would hardly be mitigated if it emerged that the victims were all old people or children or severely ill hospital patients. Suppose the same 100 people stood in need of rescue; what would lessen our sense of the moral importance of saving their lives?

Those who believe in discriminating in favor of the young or against the old must believe that insofar as murder is an injustice it is less of an injustice to murder the old than the young; it is clear that in robbing people of life you take less from them the less life expectancy they have. 
A society that accords lower priority in the allocation of resources for healthcare to the old or those with reduced life expectancy is saying, in effect, that their lives are less worth saving, in short, are less valuable. If the right or good done in saving or preserving a life is the less, then so is the wrong done in taking it, which would make, for example, the crime of murder inevitably less serious when the victims are old or terminally ill.

This may be an undesirable message to deliver for public policy as well as for moral reasons. In other words, even those who are not convinced that the moral arguments for insisting on the equal moral standing of the old are compelling, and who believe the aged to have reduced moral entitlements, might think that the message delivered by the corollary of that view was a dangerous one to brute abroad in a civilized society. The systematic disvaluing of the old or those with life-threatening illness might have a corrosive effect on social morality and community relations more generally. It might, for example, lead to an increasing tolerance of the idea that any and all resources, or even care, devoted to the old or those with life-threatening disease was a waste of time, money, and emotion. Even if this were the right view to take, the sort of society that implemented such views at the level of policy might be increasingly one in which others would feel threatened and uneasy. Moreover, once the old, however defined, had been ruled out of account, the middle-aged would become the old. They would after all have greater elapsed time "in the bank" and shorter life expectancy ahead than the rest of society and the cycle of argument and discrimination would have a tendency to extend indefinitely, a tendency moreover that would be difficult to restrain.

\section{Equal Protection}

Arguably protecting citizens against threats to their lives, liberties, and fundamental interests is the first priority for any state. When in 1651 Thomas Hobbes wrote: "The obligation of subjects to the sovereign, is understood to last as long, and no longer, than the power lasteth, by which he is able to protect them" (Leviathan, chap. 21), he was providing an answer to this question. On this view, any citizen's obligation to the State and to obey its laws is conditional on the State for its part protecting that citizen against threats to her life and liberty.

If we reflect on what citizens today want and need in the way of protection, I believe we will find that in most contemporary societies the most significant threats to life and liberty come not from the threat of armed aggression from without, but from absence of healthcare and other social welfare measures within. For most citizens, threats to their lives and curtailment of liberty looms not in the form of soldiers with "snow on their boots," but from illness, accident, and poverty. This is why it is arguable that the obligation to provide healthcare, and in particular life-saving healthcare, to each and every citizen, regardless of its affect on the aggregate health status of the community, takes precedence over the obligation to provide defense forces against external (and often mythical) enemies.

There is a very good principle that states that real and present dangers should be met before future and speculative ones. If this is right the healthcare system should have first claim on the national defense budget. No part of the argument of this paper assumes a given budget for healthcare; rather, I argue 


\section{John Harris}

that the budget could and should be larger, that the health budget has first call on the defense budget, but that whatever the budget is, there are ways of distributing the budget that are to be avoided because they are unjust.

Another feature of the nation-state's obligation to defend its citizens that is often overlooked is its egalitarian nature. Just as each citizen owes his or her obligation to obey the law regardless of such features as race, religion, gender, age, quality of life, or prognosis, so the state must discharge its obligation of protection with the same impartiality. If we expect people to obey the law even though their life expectancy is short and the quality of their life poor, we must not deny them the equal protection that is an essential part of the social contract. I have suggested that the protection of the healthcare system is one of the principal elements of the nation-state's side of this contract and that discrimination against those with poor quality of life or shorter life expectancy in the allocation of such resources is a betrayal, not only of those citizens, but also of the social contract.

Where all cannot be treated and priorities must be set, the basis of prioritization should not be the effect on the aggregate health of the whole community, for this will tend to discriminate against those arguably most in need of healthcare.

If we were to attempt to translate this into a principle for the allocation of public resources to healthcare, we might do worse than the following: The principal objective of a public healthcare system should be to protect the life and health of each citizen impartially and to offer beneficial healthcare on the basis of individual need, so that each has an equal chance of flourishing to the extent that their personal health status permits. This equal chance of flourishing should be protected regardless of such arbitrary features as race, gender, genome, wealth and power, religious belief, skin color, age, or life expectancy. ${ }^{15}$

I have talked of a public healthcare system and believe that it is every civilized state's responsibility to provide for personal and public health. Although in the United Kingdom and many other European countries there are systems, which are also provided at public expense, genuinely national healthcare systems, this is not an essential feature. A nation may choose to discharge the obligations of which I have spoken either through public or through private finance or indeed through a combination of both, supplemented by private or public insurance. The methods are much less important than the outcome. The arguments in this paper apply as much to a country like the United States, which attempts to provide for personal and public health through a mixed system, principally funded by private health insurance, as it does to a country like the United Kingdom, which pursues the same ends via a mixed system principally financed at public expense. Simona Giordano's arguments are important because they show that these obligations, however discharged, are imposed not only by personal morality (as I have argued) but also by a proper interpretation of almost all human rights protocols.

\section{Notes}

1. Dr. Giordano's work (Giordano S. Respect for equality and the treatment of the elderly: Declarations of human rights and age-based rationing. Cambridge Quarterly of Healthcare Ethics, this issue, 83-92) arises from a research project in which she and I were both involved. It was 


\section{The Age-Indifference Principle and Equality}

funded by the European Commission and granted Dr. Giordano a Marie Curie Postdoctoral Fellowship to work with me on issues of justice related to age. These two papers are a product of that research, and we are grateful to the European Commission for financial support of this work. This paper also draws on work I did for Age Concern as chair of its working party Values and Attitudes in an Ageing Society. See The Millennium Papers: Values and Attitudes in an Ageing Society. London: Age Concern England, 1999.

2. See, for example, Daniels N. Justice and Justification. Cambridge: Cambridge University Press; 1996 and Dworkin R. Life's Dominion. London: Harper Collins; 1993.

3. See Sen A. What Is Equality? In: Darwall S, ed. Equal Freedom. Ann Arbor, Mich.: University of Michigan Press; 1995 and Sen A. Equality of What? In: McMurrin S, ed. Equality, Liberty and Law. Cambridge: Cambridge University Press; 1987.

4. See, for example, Williams A. Economics, society and health care ethics. In: Gillon R, ed. Principles of Medical Ethics. Chichester: John Wiley; 1994 and Harris J. QALYfying the value of life. The Journal of Medical Ethics 1987;13:3.

5. See note 2, Daniels 1996:chap. 12; Dworkin R. Life's Dominion. London: Harper Collins; 1993:87-9, 99; and Harris J. The Value of Life. London: Routledge \& Kegan Paul; 1985:chap. 5.

6. See Daniels N. Seeking Fair Treatment. Oxford: Oxford University Press; 1995 and Dworkin R. Justice in the distribution of health care. McGill Law Review 1993;38.

7. See Cohen GA. On the currency of egalitarian justice. Ethics 1990; Dworkin R. What Is Equality, Part II. Philosophy \& Public Affairs 1981; and Dworkin R. Foundations of liberal equality. In: Darwall S, ed. Equal Freedom. Ann Arbor, Mich.: University of Michigan Press; 1995.

8. See note 5, Harris 1985:89. I have now dropped the word "fervently" (so long as they fervently wish ...) from this statement of the argument against ageism. Because we cannot sensibly measure degrees of desire, it is enough that the individuals want their lives to continue given that they understand the costs to themselves and others of granting this wish and accept those costs.

9. See, for example, Callahan D. What Kind of Life: The Limits of Medical Progress. New York: Simon \& Schuster, 1990.

10. $R$ v Carr, Law report. The Sunday Times, 30 November 1986.

11. I first articulated this principle in my chapter Ethical issues in geriatric medicine. In: Tallis, Brockelhurst, eds. Textbook of Geriatric Medicine and Gerontology, 5th ed. London: Churchill Livingstone; 1998. But its present name was suggested by members of the working party, established by The International Charity Age Concern, to investigate attitudes and values in relation to ageing. I had the honor to chair this working party, and I must thank its distinguished members for many useful insights and helpful suggestions. See note 1.

12. For example, those of the United States of America and France.

13. For example, the Universal Declaration of Human Rights (Articles 1 and 2) and The European Convention on Human Rights (especially Articles 2 and 14). See note 1, Giordano 2004, for more sources. See also Anderson ES. What is the point of equality? Ethics 1999;109(2):287-338.

14. For a discussion of other features of this sort of discrimination see my article Harris J. What is the good of health care? Bioethics 1996;10(4):269-92.

15. See Harris J. What the principal objective of the NHS should really be. The British Medical Journal 1997;314:669-72. "Genome" of course determines many of these other more readily observable features. 